jest $\mathrm{w}$ polskiej historiografii niewątpliwie nowatorska. Traktuje bowiem dwór jako pewną skostniałą strukturę, o której funkcjonowaniu decydują przede wszystkim ceremoniał i sztywne reguły. Praca ta przynosi ponadto bardzo dużo cennego materiału biograficznego (prozopograficznego), dając wgląd w skład dworu królowej.

Jerzy Dygdata (Toruń)

Nr ORCID: 0000-0002-9804-6845

\title{
Wojciech Szafrański, Józef Weyssenhoff - polityk, prawnik, legislator czasów oświecenia, Wydawnictwo Naukowe UAM, Poznań 2017, ss. 574
}

\begin{abstract}
utor recenzowanej monografii zajmował się już postacią Józefa WeysIsenhoffa, ale nie tyle „w wymiarze biograficznym”, lecz także w związ$\mathrm{ku} \mathrm{z}$ jego papierami istotnymi dla dziejów reformy humanitarnej prawa karnego w Rzeczypospolitej polsko-litewskiej pod koniec XVIII w. ${ }^{1}$ Obecnie, po wielu latach poszukiwań źródłowych (a jest to w tym przypadku
\end{abstract}

1 Por. tegoż autora: Kodeks Stanistawa Augusta, Poznań 2007. 
kwestia niezwykle skomplikowana), przedstawił nie próbę całościowej biografii Weyssenhoffa, lecz obraz kilku jego najważniejszych działań w sferze publicznej lat 1788-1792, epoki emigracji lat 1792-1794, jak i uwagi o ostatnich latach jego życia. Sprawy młodości Weyssenhoffa, kwestie rodzinne, majątkowe czy intymne pozostają w cieniu, a celem autora było ukazanie - przez studium działań Weyssenhoffa i jego otoczenia - jego roli publicznej, przedstawienie go, zgodnie z tytułem książki, jako polityka, prawnika, a zwłaszcza „legislatora”, czyli autora bądź współautora wielu ważnych dzieł ustawodawczych Sejmu Czteroletniego, zarówno tych wprowadzonych w życie, jak i pozostających w fazie projektów, bądź niedokończonych projektów. Autor napisał we wstępie (s. 8) tak: „Studium niniejsze tylko pozornie jest jedynie historią życia i działalności Józefa Weyssenhoffa, w rzeczywistości w zamyśle autora stanowić miało odpowiedź na inaczej niż dotychczas stawiane pytania o reformy ustrojowe ostatnich lat Pierwszej Rzeczypospolitej”. Tak więc autor studiuje nade wszystko materiały związane z działalnością swego bohatera jako prawnika-reformatora, a inne kwestie rysuje bądź w części wstępnej, bądź na marginesach pracy ${ }^{2}$ Stąd specyficzna konstrukcja rozprawy, która niewątpliwie jest w jakiejś mierze dyskusyjna, ma za sobą wiele za i przeciw. Lektura całości nie jest może najłatwiejsza, jest to niewątpliwie rozprawa historyka prawa. Warto tu dodać, że wiele spraw ustrojowych czy prawnych lat 1788-1795 omawiali w ostatnim ćwierćwieczu głównie historycy „ogólni”. Tu mamy spojrzenie historyka prawa i ustroju. Weyssenhoff pojawia się oczywiście w różnych opracowaniach dotyczących epoki, jednak szersze miejsce zajął chyba jedynie w monografii poświęconej nie jemu, ale jego największej miłości życia księżnej Dorocie Czartoryskiej3. Jedynym wyjątkiem był problem dużego udziału Weyssenhoffa w próbie kodyfikacji prawa ${ }^{4}$.

2 Tu trzeba dodać, zgodnie z poglądem autora, że postać posła inflanckiego zasługuje na pełne opracowanie w formie klasycznej biografii, z próbą wyjaśnienia różnych niejasności w życiorysie. Dotąd nie ma takiej biografii, a wiele kwestii wyjaśnia do dziś istotna źródłowa publikacja autorstwa pisarza Józefa Weyssenhoffa, Kronika rodziny Weyssów-Weyssenhoffów, Wilno 1935.

3 Por. M. Jastrzębska, Tajemnice księżnej Doroty Czartoryskiej, Toruń 2007.

4 Zob. przypis nr 1: we wspomnianej rozprawie Szafrańskiego Weyssenhoff pojawia się w roli ważnego humanitarysty polskiego. Obecnie, głównie na podstawie porównawczych 
Tematyka omawianej monografii jest rozległa. Muszę się więc zastrzec, że moja recenzja nie omówi wielu wątków tej skomplikowanej epoki lat 1788-1794. Wskazywałem kiedyś, że sam Bogusław Leśnodorski po latach stwierdzał, że trzeba by to studium z lat 50. na nowo napisać. Dzieje polityczne Sejmu Czteroletniego w ostatnim okresie zostały poddane nowym analizom historycznym (Łukasz Kądziela, Zofia Zielińska i inni). Z punktu widzenia historyka prawa dzieło Sejmu Czteroletniego należałoby raz jeszcze podsumować i niewątpliwie recenzowana monografia stanowi tu także istotny krok w tym kierunku.

Jeżeli chodzi o podstawę dokumentacyjną pracy, podkreślam, że autor w sporej mierze opierał się na ineditach krajowych bądź źródłach już znanych, ale na nowo odczytanych (głównie Archiwum Główne Akt Dawnych, Biblioteka Jagiellońska, Wilno, Neapol i inne archiwa). Nasze obecne możliwości szukania rozproszonych (formalnie głównie zaginionych bez wieści) tekstów związanych z bogatą rękopiśmienną spuścizną po Weyssenhoffie, a znajdujących się ewentualnie w archiwach łotewskich, białoruskich czy ukraińskich, są kiepskie5. Bogata literatura przedmiotu została

europejskich materiałów i wielu nowych ustaleń, Szafrański ujmuje odmiennie wiele kwestii, do czego wrócę we właściwym miejscu. Nota bene, w ostatnich latach napisano wiele tekstów o polskim humanitaryzmie, nieraz powtarzając już znane badania. Osobiście uważam za istotne główne ustalenia wcześniejsze Zbigniewa Zdrójkowskiego, a także niektóre prace Adama Lityńskiego i Mariana Mikołajczyka.

5 Na s. 11 autor podkreślił trudną sytuację źródłową: „Zachowane źródła wpływają na charakter pracy, stąd nie zawsze było możliwe pełne omówienie działalności posła inflanckiego i w niektórych sprawach hipotezy stawiano, które jedynie można było na podstawie obecnie znanych materiałów archiwalnych w większym lub w mniejszym stopniu uprawdopodobnić”. Gros papierów i biblioteka Weyssenhoffa uległy rozproszeniu po jego śmierci bądź w dalszym biegu wydarzeń. W pałacu w Rosi, który znalazł się później w rękach Stefana Potockiego, dziedzica księżnej Doroty, pozostała biblioteka główna. Część materiałów trafiła przez córkę Teklę do włoskiej rodziny Ludolfów, a następnie do archiwum w Neapolu. Materiały z Rosi częściowo zaginęły bezpowrotnie, znaczna część w Archiwum Akt Dawnych w Warszawie oraz w Wilnie i Charkowie. Niestety po rewolucji bolszewickiej i po dwóch wojnach światowych o spuściźnie ziemiańskiej na wschód od Wisły, a zwłaszcza od Bugu, nie da się wiele powiedzieć. Po pierwszej wojnie znawca archiwaliów, Edward Chwalewik (Zbiory polskie w ojczyźnie i na obczyźnie, t. 1-2, Warszawa-Kraków 1926-1927), opisał ówczesne straty. Pałac w Rosi nadal jeszcze istniał, choć był splądrowany. Nastąpiła całkowita zatrata archiwum Henryka Weyssenhoffa w Rusakowiczach na 
przez autora wykorzystana, dość często ujawnia on w niej błędy bądź sądy, które odmiennie koryguje.

Zgodnie ze swoimi założeniami autor podzielił pracę raczej wedle pewnych kryteriów merytorycznych niż wedle chronologii, ale ogólnie podział ten odpowiada jednak głównym epokom czy głównym zajęciom Weyssenhoffa od młodości po ostatnie lata życia. Praca w rezultacie, poza istotnymi metodologicznymi uwagami wstępnymi i swego rodzaju końcowymi zatytułowanymi Wyodrębnienie (s. 519-532), składa się z trzech części. Część pierwsza Dziatalność polityczna Józefa Weyssenhoffa (s. 19-176) obejmuje nie tylko uwagi o młodości, ale także inne wątki, takie jak Weyssenhoff jako mówca sejmowy. Rozdział czwarty to wyodrębnienie kwestii jego poglądów na temat wolności słowa i druku. Część druga, Józef Weyssenhoff jako prawnik i legislator - dziatalność w komisjach sejmowych (s. 177-464), to zasadniczy trzon pracy, rozważania bardzo źródłowe, omawiające różne aspekty działania posła inflanckiego jako autora projektów czy uczestnika działań legislacyjnych. Część trzecia Prace emigracyjne Józefa Weyssenhoffa (s. 465-518) została podzielona na cztery rozdziały: 1) Memoriat dla króla Stanistawa Augusta, 2) „O ustanowieniu i upadku Konstytucji 3 Maja" i domniemanym wspótautorstwie J. Weyssenhoffa, 3) Akt Insurekcji kościuszkowskiej, 4) Historia Sejmu Wielkiego 6.

Białorusi. W dawnej siedzibie rodu na Łotwie - Andzelmujza vel Ambenmuiza, przejętej w XIX w. przez Plater-Zybergów, przed pierwszą wojną światową istniało bogate archiwum, którego resztki do dziś gdzieś przetrwały. Lektura książki Chwalewika z pozycji historyka kultury polskiej to lektura ponura: zbiory na wschodzie uległy zatracie, bądź przepadły w nieznanych okolicznościach w latach 1916-1919, bądź zostały wywiezione do różnych miast w ówczesnej Rosji. Po grabieżach szwedzkich i carskich 1831 r. i lat późniejszych, po wydarzeniach XX w., dorobek kultury polskiej poniósł, może poza spaloną Warszawą, znów największe straty na wschodzie.

${ }^{6}$ Tekst obszernej monografii, liczącej 532 strony tekstu zasadniczego, uzupełniają wykazy skrótów, bibliografia, spis rycin, spis tabel i aneksy oraz streszczenie wielce skomprymowane. Należy żałować braku indeksu osobowego, pożytecznego dla wielu badaczy tej epoki. Aneksy zawierają dodatkowe tabele pracowicie zestawione przez autora, pozwalające np. stwierdzić pracowitość poszczególnych członków niektórych gremiów (komisji) sejmowych. W istocie grono bardzo aktywnych posłów (reformatorów czy konserwatystów) było stosunkowo nieliczne i wyraźnie wybijał się w nim także właśnie poseł inflancki. 
Recenzent nie jest w stanie równomiernie omówić poszczególnych części pracy. Należy ograniczyć się do zaakcentowania ważnych ustaleń autora oraz poruszyć niektóre kwestie dyskusyjne czy istotne pro futuro.

Średniozamożna rodzina zapewniła Weyssenhoffowi stosunkowo bogate doświadczenia. Rozpoczynając działalność publiczną, był osobą „W Europie” zorientowaną, uzyskał bardzo dobre wykształcenie lingwistyczne. Nie wszystko tu jest jasne, ale można domyślać się, że wpłynęły na to pobyt w wileńskim Collegium Nobilium jezuitów, a potem długie pobyty za granicą (1782-1787): Lipsk, Drezno, a zwłaszcza Wiedeń, gdzie studiował prawo. Ówczesny Wiedeń był w szczytowej epoce józefinizmu. Nota bene pamiętając o humanitarnej postawie posła inflanckiego, trudno nie wspomnieć, że właśnie w 1786 r. ogłoszono w Toskanii „Leopoldinę”, kodeks realizujący wiele postulatów humanitarnych, a w 1787 r. właśnie w Wiedniu ogłoszono kodeks karny Józefa II - „Józefinę”. W 1787 r. zmarł ojciec Weyssenhoffa, który musiał teraz szukać zajęcia i możliwości kariery w strefie życia publicznego. Stąd jego kandydatura na posła z Inflant w 1788 r. $^{7}$

Część pierwsza pracy ukazała dobrą pozycję, jaką uzyskał na początku Sejmu Czteroletniego w Warszawie, nie tylko jego rolę w różnych „konwentyklach", ale i jako uznanego sejmowego mówcę. Od początku należał do posłów reformatorów ${ }^{8}$, ceniono go szczególnie za prawnicze wywody

7 Sejmik inflancki, wbrew pewnej tradycji, nie wybrał zaleconych kandydatów króla, co dało także funkcję posła Weyssenhoffowi. Było to zwycięstwo rysującej się opozycji przeciw królowi (ale i za reformami). Podkreślam za autorem, że instrukcja sejmiku inflanckiego zawierała wiele elementów polityki reformatorów. Czy w jej układaniu brał udział Weyssenhoff, nie wiadomo, ale późniejsza jego działalność była nieraz zbieżna z tekstem tej instrukcji.

8 Na s. III autor napisał: „Dla wystąpień sejmowych Weyssenhoffa charakterystyczne było to, że pomimo ich znacznej liczby w toku obrad całego Sejmu Wielkiego nigdy nie były traktowane jako zwykłe gadulstwo". Dodam tu, że nawet wśród posłów obozu reform nie brakowało wystąpień czas marnujących. Rzeczowe oratorstwo Weyssenhoffa podkreślił już dawno temu Bernard Krakowski, Oratorstwo polityczne na forum Sejmu Czteroletniego. Rekonesans, Gdańsk 1968. Nota bene zaznaczę, że nie możemy tu szukać porównań ze słynnym oratorstwem rewolucyjnych polityków francuskich z lat 1789-1793. Takiej elity oświeceniowej w szerszym rozmiarze w Sejmie Czteroletnim nie było. Spora część posłów wybranych w 1788 r. nie odbiegała swym poziomem od średniego poziomu szlachty 
(sprawy podatkowe, w których wykazywał spore umiejętności, administracyjne, a także słynna karna sprawa Adama Ponińskiego) ${ }^{9}$. Już z tych analiz wynika jego rola jako prawnika: jego „mowy jurydyczne” (s. 115) to prawie $70 \%$ jego plenarnych wystąpień. Wedle autora recenzowanej pracy (s. 121) można w tym widzieć jego osiągnięcia co do doskonalenia procesu prawodawczego, co „stanowi o jego wyjątkowości i zadatkach na legislatora sejmowego, potwierdzonych także w toku jego prac w komisjach sejmowych". Rozdział czwarty nawiązuje natomiast do jego działalności jako współzałożyciela, wydawcy i redaktora „Gazety Narodowej i Obcej”, przy czym autor koryguje dawniejsze ustalenia, minimalizujące jego rolę, zarówno w sukcesach propagandy obozu reform, jaki i co do jego poglądów ogólnych na temat wolności słowa i druku, w których to kwestiach wykorzystał nieznane dotąd materiały. Ustalenia te wskazują na kluczową rolę jego wystąpień w kwestiach prawnej regulacji „wolności druku”.

W drugiej części monografii autor ukazał rolę Weyssenhoffa jako prawnika obozu reform, jako jednego z czołowych ustawodawców, działającego w komisjach sejmowych i walczącego o wprowadzenie w życie nowych przepisów. Obok najważniejszych prac ustrojowych okresu przed ostatnią fazą powstawania Konstytucji 3 maja odgrywał także znaczną rolę w wielu innych sprawach: sprawy miast, sprawy skarbowe, problem roli sejmików, osobna deputacja do spraw Kurlandii i Semigalii, w której poseł inflancki siłą rzeczy odgrywał główną rolę. Do tego sprawą wyjątkowo istotną w życiorysie Weyssenhoffa był problem reformy prawa karnego. Działał także aktywnie w Deputacji dla redakcji praw. Warto tu może zauważyć, że wśród prawodawców w Sejmie Czteroletnim brakowało osób o solidnym wykształceniu prawniczym. Każdy nieomal szlachecki polityk miał pewne nieuniknione quantum wiedzy o prawie i ustroju Rzeczypospolitej, należało to do przeciętnego kanonu wybijających się mówców sejmikowych. Natomiast

w całym kraju. Stąd w diariuszach, zwłaszcza po 1790 r., sporo przemówień nieudanych co do formy i treści.

9 Sytuację tę autor zobrazował także w formie tabeli na s. 114-115, zatytułowanej „Fazy sejmowej aktywności plenarnej Weyssenhoffa od września 1789 do maja 1792”. Jest to wykres dobitnie ukazujący epokę aktywności posła na forum plenarnym sejmu. Wiadomo, że w okresie późniejszym pracował w ogromnej mierze w deputacjach vel komisjach, które przygotowywały projekty legislacyjne. 
działalność sędziowska czy adwokacka w sądach szlacheckich nie wiązała się z reguły z żadnymi studiami prawniczymi. Nauki prawne w Akademii Krakowskiej przed reformą kołłątajowską ogólnie służyły głównie kandydatom z kół kościelnych: studium prawa kanonicznego i prawa rzymskiego. Weyssenhoff, choć nie miał dyplomu ukończenia studiów, jednak zdobył, głównie w Wiedniu i drogą samodzielnych lektur dorobku oświeceniowego, znaczne quantum kultury jurydycznej myśli oświecenia. Miał w świetle opracowanych przez Szafrańskiego materiałów istotne cechy dobrego prawnika: logiczny, uporządkowany, jasny sposób prezentowania i formutowania przepisów prawnych oraz umiejętność realistycznego interpretowania proponowanych przepisów. Na przeszkodzie tworzeniu dobrych ustaw $\mathrm{w}$ tej epoce stała niekiedy słabo rozwinięta polska terminologia prawnicza, konieczne oderwanie się od psutego nieraz w XVII-XVIII w. języka polsko-łacińskiego. Budowanie precyzyjnych sformułowań w języku niedostatecznie jeszcze w tych materiach rozwiniętym było trudnym zadaniem. Pamiętajmy, że po lata 80. XVIII w. gros polskich publikacji naukowych z zakresu prawa ciągle ukazywało się po łacinie. Nie ulega wątpliwości, że Weyssenhoff miał ten specyficzny talent myślenia w kategoriach prawnych, bez której to umiejętności, jak i dużego quantum kultury prawniczej, nie ma wybitnego prawnika.

Sprawą, od której zależała przyszłość ustrojowa Rzeczypospolitej polsko-litewskiej, była reforma sejmowania, problem stosunku nie tylko do niszczycielskiej tradycji liberum veto, ale i ogólnie problem stworzenia z szlacheckiego sejmu instytucji w miarę sprawnej, nowoczesnej. Była to kwestia trudna, napotykająca rozliczne opory ${ }^{10}$. Powodzenie (relatywne!) przedsięwzięć reformatorskich w toku Sejmu Wielkiego upatruje autor w działaniach różnych komisji czy deputacji sejmowych, które to prace „pozwalały na rzeczywiste przygotowanie projektów ustaw, w oddaleniu od izby sejmowej i właściwego ich opracowania z tak dokładnym przeanalizowaniem

10 R. Łaszewski, Sejm polski w latach 1764-1793. Studium historyczno-prawne, Warszawa-Poznań 1973, ukazał przemiany struktur formalnych między królem i sejmem a senatem. Podkreślił rolę stałych komisji sejmowych, także dla kontroli władzy wykonawczej, natomiast ich rola, w każdym razie w dobie Sejmu Czteroletniego, była także rolą zwłaszcza jako zasadniczego elementu procesu ustawodawczego. 
materii, że deputat sprawozdawca, czyli redaktor projektu był w stanie skutecznie bronić projektu w izbie sejmowej, odpowiadając na pytania posłów" (s. 179) ${ }^{11}$. Rolę Weyssenhoffa w siedmiu komisjach vel deputacjach autor opisał szczegółowo. W świetle tych ustaleń wyrasta poseł inflancki „obok Tomasza Wawrzeckiego czy Michała Bernowicza, na najważniejszego deputata prowincji litewskiej” (s. 189). Szafrański przestudiował szczegółowe materiały poszczególnych komisji dla ustalenia w ten sposób jego roli. Problem ewentualnej bezpośredniej roli w przygotowaniu ostatecznego projektu Konstytucji 3 maja jest w literaturze niejasny. Wiadomo, że gros tych spraw ostatecznie prowadzono tajnie w nielicznym gronie osób z udziałem króla. Natomiast prace deputacji sejmowych w tej kwestii zakończyło oficjalnie przygotowanie „Projektu do formy rządu” z sierpnia 1790 r., który jest uważany za niemal wyłączne dzieło Ignacego Potockiego, a liczył 658 artykułów! Wedle obecnych ustaleń Szafrańskiego udział Weyssenhoffa w tej pracy, która była formalnie przedmiotem obrad deputacji, przy czym tenże pełnił parokrotnie funkcje sekretarza, a jego ręką były pisane różne wersje pierwotne, wskazuje na jego znaczny wkład pracy u boku Potockiego. Także to on był autorem prospektu „Tymczasowe urządzenie Komisji Skarbowej Obojga Narodów", który został przezeń specjalnie opracowany w trakcie ogólnych prac tej deputacji. Kwestię tę autor obszernie omówił, wskazując na rozeznanie fachowe posła w tej skomplikowanej i spornej co do kompetencji i składu Komisji Skarbu. Szafrański napisał, że analiza tego prospektu: „Nie pozostawia wątpliwości, że poseł inflancki, układając niniejszy projekt, ewidentnie korzystał z wiedzy wyniesionej albo z wiedeńskich studiów, albo publikacji z zakresu kameralistyki i publicystyki” (s. 225). Dodam tu, że jeżeli sprawy ogólnoustrojowe Rzeczypospolitej szlacheckiej siłą rzeczy były dalekie od rozwiązań kameralistyki i nauk policyjnych, służących rozwiązaniom wprowadzanym w oświeconym absolutyzmie, to na odmianę tam, gdzie chodziło o problemy organizacyjne, strukturalne administracji państwa, sprawy podatków czy kompetencji sądowych, to nieuchronnie szukano w obozie reformatorskim rozwiązań opartych na wzorach austriackich

11 Wedle tabeli 3, s. 180-181, autor ustalił udział posła inflanckiego łącznie w 10 komisjach sejmowych, przy czym udział ten był znaczny, nieraz zasadniczy - aż w 6 komisjach (s. 179). 
czy pruskich. Zwracałem na to uwagę przed półwieczem w recenzji bogatej w treść monografii Andrzeja Zahorskiego ${ }^{12}$.

Ogólnie w sprawach sejmowych Weyssenhoff urasta do rangi niezbędnego i fachowego pomocnika, sekretarza wielu pism i projektów u boku Potockiego. Wiemy, że najważniejsze decyzje polityczno-ustrojowe co do ostatecznego tekstu Konstytucji 3 maja były podejmowane w tajnych rozmowach, w których ogólnie poseł inflancki udziału nie brał. Autor jednak ma rację, podkreślając, że długotrwałe prace sejmowych deputacji przygotowały wiele wariantów oraz rozwiązań kompromisowych i w tych pracach rola Weyssenhoffa była istotna. Ustalenia Emanuela Rostworowskiego, że ostateczny projekt konstytucji był tylko dziełem czterech osób (obok króla i Potockiego także Scipione Piattoli i Hugo Kołłątaj), są ogólnie uznawane. Przyjął je także autor recenzowanej pracy, nie znalazł bowiem konkretnych archiwalnych dowodów na rolę w tej fazie prac Weyssenhoffa. Natomiast zgodnie z istniejącymi materiałami w fazie poprzedzającej, która odegrała swoją rolę, był ważnym współpracownikiem Potockiego. Szczegółowe ustalenia Szafrańskiego co do roli posła inflanckiego w poszczególnych deputacjach pozostawiam siłą rzeczy bez szerszego omówienia. To, że w sprawach inflanckich odegrał szczególną rolę, nie ulega wątpliwości. Ciekawym problemem, dotąd niedostrzeganym, była jego rola w Deputacji Konstytucyjnej vel sejmowej w okresie już po uchwaleniu Konstytucji 3 maja: wszedł do tej deputacji 13 maja 1791 r. i przejął ogólnie funkcje sekretarza komisji, odgrywając znaczną rolę w przygotowywaniu takich istotnych ustaw, jak o Komisji Policji czy Straży Praw, a także nadal kierował sprawami Komisji Skarbowej. Uważam ten akapit pracy za istotny, wielu autorów badających sprawy uchwalania Konstytucji 3 maja często nie kontynuowało bowiem szerzej badań nad działaniami końcowego okresu funkcjonowania Sejmu Czteroletniego. Oczywiście gros projektów gotowych dopiero na przełomie 1791/1792 nie miało już szans wejścia w życie, jednak stanowią one nadal element dorobku Sejmu Wielkiego, co kiedyś w niektórych wątkach rozważał Jan Dihm.

12 Por. A. Zahorski, Centralne instytucje policyjne $w$ Polsce $w$ dobie rozbiorów, Warszawa 1959 oraz moje uwagi, „Kwartalnik Historyczny” 1960, R. 67, nr 2, s. 498-501. Por. także moje ogólne uwagi, Niemieckie Ordynacje Policyjne (XVI-XVIII w.). Uwagi o sytuacji badawczej, „Czasy Nowożytne” 2010, t. 23, s. 149-175. 
Rozdział szósty drugiej części powraca jakby do wątków rozprawy doktorskiej Wojciecha Szafrańskiego, ale w sposób zgoła nowy, wprowadzając spojrzenie porównawcze oparte na analizach nowego i starego materiału źródłowego. Świadczy o tym już tytuł rozdziału: Deputacja Kodyfikacyjna (litewska). Brissot de Warwille czy Weyssenhoff jako prawnik humanitarysta? (s. 353-447). Powstanie idei spisania - opracowania kodeksu karnego i cywilnego dla obojga części Rzeczypospolitej i ogólne dzieje tych prac (nie bez wielu wprawdzie luk w materiale źródłowym), możemy dziś uznać ogólnie za dobrze znane. Natomiast z powodu niezachowania się w źródłach protokołów Deputacji Kodyfikacyjnej Litewskiej „odtworzenie działalności tej komisji jest praktycznie niemożliwe” (s. 359). Nie jest pewne, czy w ogóle taki protokół istniał i czy poseł inflancki go jako sekretarz prowadził. Nie ulega natomiast wątpliwości, że w pracach tych dla prawa karnego w komisji litewskiej działał głównie (czy wyłącznie?) Weyssenhoff, podobnie jak w komisji koronnej Hieronim Stroynowski, z którym zresztą poseł inflancki stale współpracował. Zgodnie z ustaleniami autora pióra Weyssenhoffa są następujące teksty komisji litewskiej: 1) „Podział ogólny materii in Codice Criminali zawartej”, 2) „Obraz przestępstw publicznych i kar za nie”, 3) „Obraz przestępstw partykularnych i kar za nie”. Był także czwarty tekst pióra Weyssenhoffa jako przeredagowanie trzech projektów Józefa Szymanowskiego, zatytułowany „Myśli do tej części prospektu, w której mowa o prawach kryminalnych i procesie kryminalnym".

Wracając do tej problematyki, autor postawił pytanie o oryginalność poglądów Weyssenhoffa w świetle literatury humanitarnej europejskiej, a także o to, w jakiej mierze takie czy inne inspiracje przetwarzał w gotowy projekt kodyfikacyjny ${ }^{13}$. Józef Szymanowski i Weyssenhoff przygotowywali projekty w zakresie prawa karnego, szukając - zgodnie ze wskazówkami Kołłątaja zbliżonych rozwiązań, zwłaszcza co do systematyki materii kodeksowych.

13 Dla roli niemieckiej doktryny humanitarnej zob. D. Janicka, Komentarze K. F. Hommla do traktatu Beccarii. Przyczynek do historii literatury prawa karnego wieku Oświecenia, w: Cesare Beccaria (1738-1794), reformator prawa karnego i jego epoka, red. S. Salmonowicz, Toruń 1995. Co do późnej literatury humanitarnej (w tym Brissota de Warwille’a) w dobie pisania projektów kodeksów karnych zob. ostatnio moje uwagi: Europa w 1777 r.: od humanitarnej krytyki po budowę nowych kodeksów karnych, „Studia Juridica Toruniensia” 2017, t. 20, s. 269-297. 
Związki Weyssenhoffa z europejską literaturą humanitarną, z dziełem Beccarii na czele (egzemplarz dzieła był własnością posła) są niewątpliwe. W swych znanych dziś tekstach powoływał expressis verbis obok Beccarii tylko Monteskiusza i marginesowo Beniamina Franklina. Obecnie po nowej analizie całości tekstów autor postawił pytanie, czy owe teksty należy uznać za „plan szczegółowej części prospektu prawa kryminalnego", czy raczej tylko traktować je jako prace wstępne, które w istocie są polską adaptacją tekstu francuskiego, który dopiero „miał się stać podstawą do stworzenia projektu?” (s. 375). Otóż odpowiedź Szafrańskiego na to pytanie brzmi tak, że wszystkie trzy prospekty piór posła inflanckiego „stanowią adaptowane (nieznacznie) przez niego tłumaczenia pracy Jacques-Pierre Brisstota de Warwille", jego dzieła Théorie des lois criminelles z $1781 \mathrm{r}$. Osobiście nigdy nie prowadzitem analizy szczegółowej tych tekstów wobec istnienia bogatej literatury przedmiotu (już przed Szafrańskim pisali na ten temat Zbigniew Zdrójkowski, 1956, 1958, parokrotnie Adam Lityński, 1974 i późniejsze teksty). Obecne wywody - porównanie tekstów Brissota de Warwille’a i prospektów Weyssenhoffa - jest w pełni, moim zdaniem, przekonujące. Powstaje pytanie, czy przejmując lub propagując rozwiązania Brissota de Warwille'a, Weyssenhoff był zdecydowanym zwolennikiem tych rozwiązań, czy jedynie przedstawiał te propozycje do dyskusji. Autor monografii podkreśla funkcjonujące ówcześnie w Europie rozprawy Brissota. Jest to zgodne z moimi badaniami w tym względzie ${ }^{14}$. Podkreślenia wymaga dobra orientacja Weyssenhoffa we francuskiej terminologii prawniczej. Niekiedy jednak omawiane teksty pomijały czy zmieniały francuski tekst. Tak czy inaczej „prospekt kodyfikacyjny Weyssenhoffa oparty na koncepcjach Brissota stanowił dla wielu ówczesnych absolutne novum" (s. 384). Autor prospektu nie powołał się expressis verbis na Brissota, w ówczesnej sytuacji politycznej byłoby to bowiem niekorzystne.

14 We Francji ciągle nie docenia się Brissota de Warwille'a jako pisarza niepokornego przed 1789 r., co wiąże się z wpływem tendencji jakobińsko-komunistycznych w historiografii: Brissot był ciągle widziany głównie jako nieudolny przywódca Żyrondy. Ostatnio nie docenił tej postaci specjalista teorii prawa karnego Christoph Luther, Aufgeklärtstrafen. Menschengerechtigkeit im 18. Jahrhundert, Frankfurt a. M. 2016, s. 316, pisząc o Brissocie tak: „Sein Schwerpunkt ist die Rechtspolitik. Rechtsdogmatisch überzeugt es kaum. Aus juristische Perspektive besteht deshalb ein erhebliches Missverständnis zwischen Umfang und Ertrag dieser Preisschrift". 
Wiele uwagi poświęcił Szafrański problemowi kary śmierci w ujęciu Brissota-Weyssenhoffa (s. 403-419) ${ }^{15}$. Nie wiemy, niestety, jak wyglądałby ostateczny projekt kodeksu karnego w ujęciu posła inflanckiego, ale w ścisłej współpracy z Józefem Szymanowskim.

Tylko kilka uwag przeznaczyłem na kwestię istotnej (ale i pogmatwanej w świetle skąpych źródeł) działalności emigracyjnej Weyssenhoffa. Autor podzielił trzecią część pracy - jak wspomniano wyżej - na cztery rozdziały nie tyle wedle chronologii, ile wedle wątków problemowych. Ostatni rozdział czerpie swój tytuł z pracy, którą pod tym tytułem („Historia Sejmu Wielkiego”) ówcześnie pisał poseł inflancki. Weyssenhoff opuścił Polskę, udając się do Lipska, ok. 1 sierpnia 1792 r. (król już 23 lipca ogłosił swój akces do Targowicy). W Lipsku i Dreźnie zebrał się obóz reformatorów, w którym Weyssenhoff odgrywał rolę znaczną, choć nie zawsze wyjaśniają ją źródła. Ignacy Potocki i wielu polityków obozu reform marzyło ciągle o jakimś kompromisie z Rosją i królem. Dwuznaczną, a właściwie jednoznaczną rolę odgrywał wśród nich Piattoli, człowiek w każdej sytuacji działający tylko w interesie Stanisława Augusta. Faktem jest, że mimo sceptycyzmu Weyssenhoff był współautorem memoriału dla króla i także tzw. listu Stanisława Augusta, napisanego przez emigrantów dla króla w nadziei uzyskania, wbrew istnieniu konfederacji targowickiej, jakiegoś kompromisu z Rosją. Niewątpliwie po klęsce sprzeczne pomysły kierowały wybitnymi przedstawicielami obozu reform. Już jednak w 1793 r. pozostawała tylko droga walki w obronie niepodległości kraju i we współdziałaniu z rewolucyjną Francją, bo innego sojusznika na horyzoncie nie było widać. Francja była już wówczas radykalną republiką. Rozmowy z tym państwem miał

15 Szafrański (podobnie jak kiedyś Igor Andrejew z perspektywy represyjnego prawa karnego w PRL-u) kładzie nacisk na to, że Beccaria dopuszczał wyjątkowo stosowanie kary śmierci. W istocie dopuszczał „unicestwienie” sprawcy niebezpiecznego, ale nie jako karę, bowiem tylko „w sytuacji anarchii, w której ludzie jakby wracają do stanu sprzed umowy społecznej"; S. Salmonowicz, Z wieku Oświecenia. Studia z dziejów prawa i polityki XVIII w. Toruń 2001, s. 45. Beccaria był więc abolicjonistą. Nota bene dylemat, czy w pewnych sytuacjach kara śmierci nie jest na nowo potrzebna, powraca w obliczu masowych działań terrorystów; por. S. Salmonowicz, Cesare Beccaria, kara śmierci i wspótczesny terroryzm, w: Nam Hoc Natura Aequum Est. Ksiega jubileuszowa ku czci profesora Janusza Justyńskiego w siedemdziesięciolecie urodzin, Toruń 2012, s. 131-140. 
prowadzić Weyssenhoff, jednak ostatecznie odmówił wyjazdu do Paryża. Pojechał tam Tadeusz Kościuszko, który stał się wodzem przygotowywanego w kraju powstania ${ }^{16}$. Autor ustalił, że w pisaniu dzieła $O$ ustanowieniu i upadku Konstytucji 3 Maja także nie wziął udziału. Zdaniem Szafrańskiego miał ambicję przygotowania dzieła rzetelnego, źródłowego, o działaniach Sejmu Czteroletniego i nie chciał być współautorem publicystyki politycznej w niejednym dalekiej od faktów, zwłaszcza lat 1790-1791. Pomógł jednak Samuelowi B. Lindemu w tłumaczeniu tego dzieła na niemiecki. Problem udziału posła inflanckiego w przygotowywaniu i przebiegu insurekcji 1794 r. jest wysoce niejasny. Akt insurekcji przygotowywany w Dreźnie był także, na życzenie Kościuszki, poprawiany czy uzupełniany przez niego. Weyssenhoff miał wówczas proponować, by forma ostateczna ustroju kraju miała pozostać do dalszych decyzji narodu. Prawdopodobnie Weyssenhoff miał wywrzeć znaczny wpływ na planowany ustrój tymczasowych władz insurekcji. Faktem jest, że w momencie ogłaszania aktu insurekcji (w jej ostatecznym kształcie) nie było go u boku Kościuszki i nawet do dzisiaj jest dyskusyjne, czy w ogóle przybył on do kraju. Jest wprawdzie relacja Antoniego Bauma, że wraz z generałem Józefem Zajączkiem wyjechał z Drezna do Polski. Istnieje także możliwość, że 10 kwietnia wraz z Lindem przybył do Krakowa. W znanych nam źródłach brakuje informacji o jego roli w Krakowie czy w Warszawie. Wiadomo tylko, że figurował na liście członków Rady Najwyższej Narodowej (powołanej 10 maja) ${ }^{17}$.

W rozdziale czwartym drugiej części autor opisał skąpe informacje o przygotowywanym przez niego opisie dziejów Sejmu Czteroletniego ${ }^{18}$.

${ }_{16}$ Ta odmowa to jedna z zagadek jego życiorysu. Podejrzewam, że w tej i w innych kwestiach kierował się wpływem na niego Doroty Czartoryskiej, która, jak sądzę, była przeciwna jego działalności politycznej.

17 Bliskie wówczas związki z Lindem, który w czasach insurekcji miał opinię radykalnego jakobina, także nie są jasne. Magdalena Jastrzębska wyraziła pogląd, że Weyssenhoff był jednak do końca insurekcji w Polsce. Moim zdaniem jest to niemożliwe. Najbardziej prawdopodobne są hipotezy, że bądź w ogóle nie dotarł do Krakowa, bądź wkrótce potem wrócił do Drezna. Trzeba pamiętać, że z pewnością usiłował unikać orientacji policji saskiej w swoich podróżach. Być może główną przyczyną były jego narastające kłopoty zdrowotne, o których wiele nie wiemy.

18 Było to główne jego zajęcie w latach 1795-1798, wcześniej już planowane. Wedle Szafrańskiego były to $\mathrm{w}$ istocie dwa odrębne projekty: pierwszy, jeszcze w latach 
W uwagach końcowych autor monografii nie podsumował jej szerzej, kładąc nacisk tylko na kilka elementów. Pierwszy, że koleje działalności publicznej Weyssenhoffa to przykład awansu do elity politycznej kraju nie przez majątek czy funkcje życia politycznego szlacheckiego, ale przez nowe formy aktywności politycznej (kierowanie gazetą obozu reform, umiejętności prawnicze w dobie koniecznej ,jurydycznej”, legislacyjnej polityki obozu reform). Podkreślenia wymaga także ogólnie oświeceniowa mentalność posła inflanckiego, jego pewien radykalizm społeczny, a zwłaszcza jego umiejętności oratorskie i redakcyjne u boku głównych polityków obozu reform.

Pora na kilka słów podsumowania uwag recenzenta. Otrzymaliśmy monografię ambitną, opartą w dużej mierze na studium źródeł. Możliwe są tu pewne dalsze dyskusje, autor nie lęka się sporów, potrafil nawet odejść od swoich dawniejszych sądów. Nie ulega wątpliwości, że ta monografia stanowi pewien istotny krok w ogólnych dyskusjach na temat dzieła Sejmu Czteroletniego. Istniejąca obszerna, kontrowersyjna literatura przedmiotu została wzbogacona w istotnych elementach, zwłaszcza co do dyskusji nad rolą poszczególnych osób w dorobku ustawodawczym (w tym projektów, które nie weszły w życie) Sejmu Wielkiego. Postać Józefa Weyssenhoffa, choć niektórych zagadek życiorysu w pełni się nie udało rozwiązać, zyskała wiele nowych aspektów i nie ulega wątpliwości, że autor omawianej monografii włożył w nią sporo wysiłku, który trzeba docenić.

Stanistaw Salmonowicz (emerytowany pracownik UMK w Toruniu)

wcześniejszych w Dreźnie plan opracowania (może zespołowego) całokształtu ustawodawczego Sejmu Czteroletniego pod nazwą „Projekt edycji”. Miała to być raczej kompilacja źródeł, które zbierał w tych latach. Ten ambitny program nie został poza wstępnymi pracami zrealizowany. Drugi projekt to była już jego własna próba nakreślenia obrazu działalności Sejmu Czteroletniego. Oryginał niedokończonego dzieła trafił do spuścizny córki Tekli, która we Włoszech wyszła za Constantina Ludolfa. Te materiały trafiły do archiwum w Neapolu i uległy zniszczeniu (?) w toku bombardowania alianckiego w 1943 r. Posiadamy jednak część informacji, które z tego archiwum odpisał potomek rodu - pisarz Józef Weyssenhoff, i te materiały autor omówił. 